\title{
SVIJET (NI)JE NAUČIO LEKCIJU IZ FINANCIJSKE KRIZE
}

\author{
Ante Gavranović \\ Hroatsko komunikološko društvo, Zagreb, Hrvatska
}

\section{Sažetak}

Velika financijska i ekonomska kriza pravi su školski primjer ekonomske katastrofe neshvatljivih razmjera. Iako (do danas) još uvijek nema konsenzusa o uzrocima ove krize, većina stručnjaka prepoznaje krivce za krizu, ponajviše u financijskom sustavu koji se odmaknuo od kontrole i izbjegava regulaciju i nadzor. Više od deset godina nakon početka financijske krize, centralni bankari i političari tapšu po leđima: najgore je iza nas i oporavak je učinjen. Greška. Samo je pitanje vremena do izbijanja krize. I to punom snagom ... Makroekonomski indeks otpornosti (kojeg su zajedno razvili švicarski institut SRE - Swiss Re i britansko sveučilište LSE - londonska ekonomska škola) pokazuje da je globalna ekonomija danas manje otporna na globalnu financijsku krizu nego 2007. Analiza pokazuje da je 80 posto zemalja (koje pokrivaju 31 zemlju s $75 \%$ udjela u svjetskom BDP-u) sada ranjivije $u$ tom pogledu, uprkos činjenici da su financijske institucije jače nego što su bile na početku krize. Nedavno je na blogu Svjetske banke objavljen članak čiji je autor Augusto Lopez-Claros, bivši direktor Globalnih pokazatelja i analitičar Svjetske banke. Zanimljiv je iz više razloga: posebno jer se zalaže za fiskalnu stabilizaciju u narednim godinama. Upozorio je da je danas u mnogim zemljama javni dug na razini zadnji put viđenoj na kraju Drugog svjetskog rata. Prema njegovom mišljenju, neki oblik fiskalne konsolidacije, podržan drugim strukturnim i institucionalnim reformama, možda će biti jedini održiv put u narednim godinama. U prilog ovoj tvrdnji iznosi i tri argumenta. To su sveukupno smanjeni fiskalni prostor, zatim povećani srednjoročni pritisci i, konačno, volatilnost financijskog tržišta. Kako su novinari i opće poslovno novinarstvo reagirali na početak financijske krize i što smo naučili iz nje? Je li nova financijska kriza stvarno na putu?

\section{Ključne riječi}

financijske krize, financijski sustavi, ekonomska teorija, razumijevanje ekonomske logike, rješavanje problema 


\section{Uvodna razmatranja}

Velika financijska i gospodarska kriza predstavlja pravi školski primjer ekonomske katastrofe nesagledivih razmjera. Iako (i danas) još nema punoga konsenzusa oko razloga te krize, većina stručnjaka prepoznaje krivce krize ponajviše u financijskom sustavu koji se otrgao kontroli te izbjegao regulaciji i nadzoru.

Deset godina nakon početka financijske krize, središnji bankari i političari se tapkaju po leđima: najgore je iza nas i oporavak je obavljen. Greška. Samo je pitanje vremena prije nego što kriza opet pukne. I to s punom snagom... /1/ Indeks makroekonomske otpornosti (zajednički su ga razvili švicarski institut SRE - Swiss Re i britansko sveučilište LSE - London School of Economics) pokazuje da je svjetska ekonomija danas manje otporna na globalnu financijsku krizu nego što je bila 2007. Analiza tako pokazuje da je 80 posto zemalja (obuhvaćeno je 31 zemlja sa 75-postotnim udjelom u svjetskom BDP-u) u tom pogledu sada ranjivije, unatoč činjenici da su financijske institucije osnažene i jače su nego što su bile na početku spomenute krize. Kao argument se navodi da su raspoloživi amortizeri za suzbijanje krize danas slabiji nego tada.

Kako su novinari i ukupno poslovno novinarstvo reagirali na pojavu financijske krize i što smo uopće naučili iz nje? Je li nova financijska kriza zaista na pomolu? /2/

\section{Poziv na fiskalnu konsolidaciju}

U blogu Svjetske banke nedavno je objavljen članak čiji je autor Augusto Lopez-Claros, bivši direktor globalnih pokazatelja $\mathrm{i}$ analize $\mathrm{u}$ Svjetskoj banci. Zanimljiv je iz više razloga: posebno jer se zalaže za fiskalnu stabilizaciju u narednim godinama /3/. Upozorio je da je $u$ mnogim zemljama javni dug danas na razinama koje su posljednje viđene na kraju drugog svjetskog rata. Po njegovom mišljenju neki oblik fiskalne konsolidacije, uz potporu drugih strukturnih i institucionalnih reformi, može biti jedini održiv put u nadolazeći godinama. On navodi i tri argumenta koja podržavaju ovu tvrdnju. To su ukupno smanjen fiskalni prostor, zatim povećani srednjoročni pritisci i, konačno, nestabilnost financijskih tržišta $/ 4 /$.
Postoje vjerodostojni ekonomisti (čak i nobelovci) koji tvrde da je globalni financijski sustav inherentno nestabilan, da ne postoji jamstvo da se neće srušiti u budućnosti kao rezultat zlostavljanja, pogrešnog ponašanja ili drugih čimbenika koji nisu povezani s onima koji su izazvali posljednju krizu. Robert J. Shiller $/ 5$ /, vodeći promatrač financijskih tržišta i onaj koji je izdao ponovljena upozorenja o mjehurićima $\mathrm{u}$ gospodarstvu u Sjedinjenim Američkim Državama, misli da su "kapitalistička gospodarstva, ostavljena vlastitim uređajima, bez uravnoteživanja vlada, u suštini nestabilna“. Ono što čini "noćnu moru" je scenarij da je sposobnost pojedinih vlada da spriječe gospodarsku depresiju kroz razne intervencije, kao što su one raspoređene u 2008-2009., bitno sužena i ovisit će o funkciji zdravlja vlastitih financija. Poanta je da bi još jedna financijska kriza mogla staviti iste vrste pritiska na proračune koje smo vidjeli nakon 2008., s time da je sada polazna točka, u smislu razine duga, mnogo nepovoljnija.

„Pogrešno je misliti da bi opuštanje proračunskih pravila, što bi omogućilo veće deficite i odgovarajuće veće razine duga, eliminirati potrebu za bolnim i dugim zakašnjelim reformama koje su vrlo zaduženim zemljama tako očajnički potrebne. Održivi gospodarski oporavak - ključan za uspješno rješavanje problema s dugom - doći će samo kada vlade provedu reforme koje će pomoći u uklanjanju prepreka koje su dugo potkopale konkurentnost i smanjile potencijalni rast" tvrdi Lopez-Claros.

Ovakve situacije i razmišljanja sigurno će potaknuti mnoge teoretičare $i$ praktičare ekonomije da evoluciji, metodama, problemima i perspektivama svog odabranog područja pristupe na drukčiji način. Ono što danas uglavnom nedostaje ekonomistima jest kreiranje velike slike. Parcijalni pristup razumijevanju ekonomske logike i rješavanja ekonomskih problema dovodi nas u situaciju podvojenosti - kome vjerovati i koga slijediti.

Veliki ekonomski mislioci prošlosti, Smith, Ricardo, Keynes, Marx, Schumpeter i Galbraith, nisu koristili matematičke metode i deduktivnu logiku, što je već decenijama glavni alat dobitnika Nobelove nagrade iz ekonomije. Glavno analitičko oruđe istinski velikih 
ekonomista nije bila formalna logika, nego snaga argumenata koja je pokretala mase. Nedvojbeno, vladajuća i pogrešna ekonomska teorija današnjice počiva na ideji nereguliranog kapitalizma sažetoj u rečenici čuvenog Paula Samuelsona koji smatra "da je poznati austrijski ekonomista Joseph Schumpeter pogriješio u mišljenju da postoji vremenski raspored kada će kapitalizam nestati".

Makroekonomisti su potpuno zanemarili ulogu psihološkog faktora. Naime, većina ljudi ekonomske odluke ne donosi razumom i logikom, nego emocijama i osjećajem. Tvrdeći da je ljudsko ponašanje sasvim racionalno i predvidljivo, kvantitativni ekonomisti su svojim modelima pomagali (samo)zavesti bankare i političare, a ekonomska kriza je pokazala da je njihova sposobnost predviđanja bila ništavna.

\section{Utjecaj informacije na političku i gospodarsku moć}

U suvremenoj povijesti pokazalo se da je $u$ rukama onih koji imaju pravodobnu i točnu informaciju koncentrirana i politička i gospodarska moć. Razvoj događaja u svjetskoj privredi, posebno kad je riječ o know-how i transferu tehnologije, o tehnološkim informacijama, istraživanju tržišta i marketinga $\mathrm{u}$ cjelini, doveo je do ogromnog raskoraka $\mathrm{u}$ društvenom proizvodu i među najrazvijenijim zemljama. Znakovito je, kažu John Nesbith i Patricia Aburdane: „U industrijskom razdoblju, kad je strateški resurs bio kapital, cilj korporacije mogao je biti samo profit. U informacijskoj eri, naprotiv, strateški resurs su informacije, znanje i kreativnost" /6/.

Analitička vrijednost svake, a posebice poslovne informacije je, tako barem smatraju najveći stručnjaci-teoretičari - $\mathrm{u}$ neposrednoj proporciji s vjerodostojnošću i strukturom podataka iz kojih se oni izvode kao ekstrakti. Posebnu važnost pritom ima stručna njihova selekcije i kvaliteta obrade. Bez tih faktora informacija može prerasti u svoju suprotnost postati dezinformacija ili poluinformacija. I jedno i drugo je na svojevrstan način obmanjivanje javnosti. Pojavom "fake news" stanje se osjetno pogoršalo.

Ovisnost gospodarstva - zadržimo se samo na tom području - o informacijama je, međutim, postala praktično nezamjenjiv element upravljanja poslovanjem i financijama. Zašto su te informacije toliko važne? Danas neke poslovne ili razvojne odluke zahvaćaju ili bitno utječu na sve veće gospodarske i društvene vrijednosti. Istodobno, raste spoznaja da se najveći broj pogrešnih poslovnih odluka donosi upravo iz pomanjkanja potrebnih i pravovremenih informacija, što je $u$ suvremenim uvjetima jednako poslovnoj nepismenosti. Postoji realna opasnost da tu upadnemo u prvu zamku. Kako da se poslovan čovjek $\mathrm{u}$ bujici informacija koje mu stoje danas na raspolaganju - ako se zna njima služiti i ima odgovarajuću infrastrukturu - a riječ je o stalnom, nekontroliranom, neselekcioniranom i neusmjerenom dotoku informacija - podvede osnovnoj funkciji: da mu informacija služi proširenju znanja i olakša donošenje poslovnih i razvojnih odluka?

Pokazalo se, naime da KOLIČINA INFORMACIJA sama po sebi nije garancija da će spoznaja biti dovoljna i da će pružati bolje mogućnosti za donošenje zaključaka ili odluka u nekom pitanju. Danas stoga imamo gotovo paradoksalnu situaciju: još nikada nije bilo tako mnogo informacija - dakle dostupnog, pripremljenog i uskladištenog znanja - kao što je to slučaj danas. Pa ipak, još nikada se nije toliki broj ljudi osjećao nedovoljno ili loše informiran. Naime, uz plimu informaciju dolazi i njena oseka i samo umjereni ritam plime i oseke može čovjeku dati pravu mogućnost korištenja informacije $/ 7 /$.

U pokušajima da se osvijetli kako se dolazi do informacija glavni se naglasak stavlja na nedovoljne mehanizme međusobnog komuniciranja medija-novinara i izvora informiranja. Činjenica je da se u tim uvjetima traže i neprimjereni putovi do informacija, što počesto onemogućava provjeru informacije $\mathrm{i}$ njene točnosti. Na temelju toga nastaju ozbiljni nesporazumi na relaciji mediji- gospodarstvo.

Druga dimenzija ovog fenomena jest "kvadratura zatvorenog kruga", a odnosi se na često nedovoljno stručnu osposobljenost ekonomskih analitičara i gospodarskih novinara da prate sve svjetske procese (posebno globalizacije $i$ integracije te financijskih kretanja), što očito traži još veću specijalizaciju prema određenim područjima. Najnoviji 
domaći primjeri sloma Agrokora, Uljanika, Trećeg maja - da spomenemo samo njih opetovano potvrđuje temeljnu tezu: ekonomisti i poslovni novinari najčešće nisu dovoljno osposobljeni da prate duboke $\mathrm{i}$ izrazito sofisticirane procese globalizacije i internacionalizacije svjetskoga gospodarstva čiji smo (sve više) sastavni dio odnosno da na njih pravodobno reagiraju /8/.

\section{Svijet nije naučio lekcije o financijskoj krizi}

Kada povjesničari gledaju unatrag u početak 21. stoljeća, oni će identificirati dva seizmološka šoka. Prvi je bio teroristički napadi 11. rujna 2001 na njujorške „blizance“, a drugi globalna financijska kriza, koja je prije jedanaest godina „proključala“ s kolapsom Lehman Brothersa. Jedanaesti rujna doveo je do ratova; bankrot Lehman Brothers otvorio je prostor za žestoki ekonomski i politički obračun te "oslobodio" prostor za kaos na financijskim tržištima.

Jedan od rijetkih ekonomista koji je upozoravao na dolazak velike krize koja je i nastupila 2008. godine, Nouriel Roubini, smatra da se nalazimo pred novim globalnim ekonomskim kolapsom. Uzročnike vidi u politikama Donalda Trumpa, trgovinskom ratu, velikim dugovima i nedovoljnom gospodarskom rastu /9/.

Profesor ekonomije s Univerziteta New York ponovo je upozorio na nadolazak ozbiljne recesije, pa $i$ krize $s$ novim crnim predviđanjima. U tekstu koji je za Financial Times napisao $\mathrm{u}$ suradnji $\mathrm{s}$ profesorom $\mathrm{s}$ Londonske škole ekonomije Brunellom Rosom, Roubini ističe da će spor ekonomski rast, fiskalni stimulans koji dolazi u pogrešnom trenutku i trvenja na planu trgovine koja se mogu pretvoriti $u$ trgovinske ratove, do nove krize dovesti već 2020 /10/.

„Dok obilježavamo desetu godišnjicu globalne financijske krize, pojavljuju se brojne autopsije u pokušaju ispitivanja njenih uzroka, posljedica $i$ pitanja jesu li važne lekcije naučene. Zato je prigodan trenutak da se zapitamo kad će se i zašto dogoditi naredna recesija $i$ financijska kriza. Globalna ekspanzija će se vjerojatno nastaviti i u narednoj godini (2019., op.p) uslijed velikih fiskalnih deficita Sjedinjenih Američkih Država, Kina će nastaviti s politikom podsticaja, a Evropa ostaje na putu oporavka. Ipak, postoji nekoliko razloga zašto bi se uvjeti za globalnu recesiju i financijsku krizu mogli pojaviti do 2020. godine“, pišu Roubini i Rosa, uspostavljajući paralelu s razdobljem u kojem se dogodio kolaps banke Lehman Brothers i prateća globalna ekonomska kriza te upozoravajući na faktore koji bi u naredne dvije godine mogli dovesti do slične situacije.

Spor ekonomski rast jedan je od najvažnijih uzroka krize koju predviđaju Roubini i Rosa. Autori ističu da ekonomija Sjedinjenih Američkih Država i drugih zemalja trenutno bilježi rast, ali da je taj rast vođen politikom fiskalnih i monetarnih podsticaja koji su doprinijeli stopi rasta američke ekonomije čak dva postotna boda iznad potencijalne stope rasta, te da će rast uskoro izblijedjeti jer nije dugoročno održiv. Dvojica ekonomista smatraju da će, uslijed visoke stope inflacije, Federalne rezerve postrožiti fiskalnu politiku, nastavljajući podizati svoju referentnu kamatnu stopu do razine od 3,5 posto do početka 2020. godine, što će usporiti ekonomski rast. Prateći američku centralnu banku, ostale centralne banke će vjerojatno početi ili nastaviti normalizirati svoje politike, vodeći na kraju do slabije ekspanzije i veće inflacije.

Uzroke novoj krizi Roubini i Rosa $u$ mnogočemu pripisuju politikama američkog predsjednika Donalda Trumpa, navodeći da će se problem i američka trvenja s Kinom i Europom dalje pojačavati, pa možda čak izazvati pravi trgovinski rat.

"Ova trvenja su samo simptomi mnogo dubljeg nadmetanja za globalno vodstvo u tehnologijama budućnosti, ali će njihova posljedica biti spor rast $i$ povećanje inflacije", navode eminentni autori. "Donald Trump već sada napada Federalne rezerve, dok ekonomski rast premašuje četiri posto. Što će raditi 2020., izborne godine, kad se rast zaustavi na malo iznad jedan posto, a broj radnih mjesta počne smanjivati?", pitaju se autori, navodeći da se može dogoditi da Trump pokrene krizu u vanjskoj politici, naročito ako ga pri odlukama u unutrašnjoj politici budu onemogućavali demokrati. "Napokon, jednom kad se ova velika oluja pojavi 2020. godine, oruđa dostupna vladama bit će ograničena",ističu autori na kraju /11/.

\section{Nova recesija pred vratima}

$\mathrm{Na}$ tržištima su sudionici sve više zabrinuti zbog mogućnosti ozbiljnog gospodarskog 
usporavanja u nadolazećim mjesecima, kao i zbog dugoročnog trgovinskog rata SAD-a i Kine, koji utječe na poslovno i potrošačko raspoloženje. Većina ekonomista, kao i neke svjetske poslovne elite, slažu se $u$ ocjeni da se gospodarski rast usporava (na svjetskoj razini), ali se političari nadaju kako će se to postepeno događati te da recesija neće naglo nastupiti.

Paul Krugman, međutim, smatra kako postoje ozbiljni razlozi zbog kojih sumnja $\mathrm{u}$ takav scenarij /12/. Malo je vjerojatno da će samo "jedna velika stvar" potaknuti globalan gospodarski pad, nego će se raditi o nizu utjecaja. Poticaj smanjenja (korporativnog) poreza od strane američkog predsjednika Donalda Trumpa jedan je od razloga za Krugmanovu zabrinutost, jer prema njegovom mišljenju taj program "nije baš učinkovit". Već se nazire da se "balon ispuhuje" kada se radi o rastu tehnološkog sektora. Među kreatorima gospodarskih politika ne postoji pripremljenost za recesiju. "Glavna zabrinutost je uvijek bila da ne postoji učinkovit odgovor ako se stvari uspore. Mjesto koje trenutno izgleda vrlo blizu recesiji jest eurozona", dodao je. Europska komisija, znakovito, oštro je snizila svoju prognozu za gospodarski rast eurozone u 2019. i 2020. godini. Vijest o usporavanju rasta ozbiljno je uzdrmala i ujedno povećala strahove da se globalni gospodarski pad širi na Europu /13/.

\section{EKONOMSKI}

NOBELOVCI

\section{UPOZORAVAJU}

Njemački Die Welt upitao je još 2017. godine 18 dobitnika Nobelove nagrade za ekonomiju o tome prijeti li svijetu nova financijska kriza poput one koja je 2008. uzdrmala globalnu ekonomiju. Odgovor najvećih svjetskih ekonomskih stručnjaka je jedno iznimno zabrinjavajuće "DA" /14/. Ekonomski nobelovci ne vjeruju baš izjavama Janet Yellen, bivše šefice američkog Sustava federalnih rezervi (tj. Narodne banke), koja je krajem lipnja te godine izjavila da "za naših života više neće biti financijske

krize". Dobitnik Nobelove nagrade za ekonomiju 2016. godine Bengt Holmström smatra da Yellen griješi: "Ne bih se kladio da neće biti krize. Kad god smo uvjereni da više neće biti krize banaka, rizik se zapravo povećava." Njegov kolega Edward Prescott, ekonomski nobelovac iz 2004. godine, ima još mračnije predviđanje: "S velikom sigurnošću možemo očekivati novu financijsku krizu u ne tako dalekoj budućnosti." Ekonomske nobelovce posebno brine što je moguća svjetska financijska kriza političarima nevažna tema. $\mathrm{Nju}$ su u zapećak gurnuli terorizam, potencijalni nuklearni sukob SAD-a i Sjeverne Koreje, novo sučeljavanje s Iranom i stalni ispadi novog američkog predsjednika Donalda Trumpa pa se ne posvećuje dovoljno pažnje nestabilnosti financijskih sustava i gospodarskim problemima. Nobelov laureat iz 2007. Eric Maskin predviđa da bi Trumpova ekonomska politika, u kojoj se najavljuje velike deregulacija Wall Streeta, mogla ubrzati dolazak nove globalne financijske krize. "Ako sadašnja američka administracija odluči olabaviti postojeća pravila, kriza je sve vjerojatnija", smatra Maskin.

Ekonomski nobelovac iz 2000. Daniel McFadden nudi još strašnije predviđanje: "Financijske krize kreću se kao električna energija kroz jednu veliku mrežu. Kao i kad je riječ o struji, neizbježni su kratki spojevi. Mi danas nemamo odgovarajuće instrumente da bismo te nestabilnosti nadgledali, regulirali i njima upravljali. Zbog toga je nova financijska kriza jednostavno neizbježna." McFadden nema vjere ni $\mathrm{u}$ ekonomsku stabilnost eurozone, a time ni cijele Europske unije.

Nobelovac Prescott dodaje kako je "vrlo pesimističan u vezi eura" i da je "pravo pitanje koliko će štete euro nanijeti članicama eurozone prije potpunog kolapsa". Ključni problem za Prescotta je taj što su članica EU-a izgubile suverenitet odlučivanja u ekonomskoj politici te upozorava na to da se članicama mora omogućiti mogućnost da - bankrotiraju. Ekonomski nobelovac iz 2002. Vernon Smith ipak smatra da bi euro mogao prosperirati, ali zahvaljujući tome što "SAD u globalnom natjecanju valuta gubi pozicije zbog loše pozicije dolara".

Ekonomski nobelovci su još upozorili na opasnost klimatskih promjena koju vide kao najveću prijetnju stabilnosti svijeta te na sve brži razvoj robotike i automatizacije koji će dovesti do toga da će strojevi oduzeti ljudima milijune radnih mjesta. 


\section{Nije pitanje ako, nego kada}

Zbog američkog "pumpanja" gospodarstva, odnosno fiskalnih i monetarnih poticaja kojima se potiče rast, već iduće godine, najkasnije do 2020. svijet bi mogla zadesiti kriza. Analitičari već dvije godine ističu takav crni scenarij, koji će osobito teško pogoditi Europu, s obzirom da nema jedinstvenu fiskalnu politiku niti prevelik arsenal ekonomskih alata kojima bi mogla utjecati na svoje gospodarstvo, što se itekako osjetilo u prošloj krizi.

Ben Bernanke, bivši šef FED-a (Američke centralne banke) istaknuo je da će se američka ekonomija suočiti s "Wile E. Coyote momentom u 2020., jer će tada ekonomija ostati bez različitih oblika potpora i stimulacija".

Francuska banka Société Générale također je upozorila na recesijska očekivanja u 2020., i to zbog neravnoteža na tržištu rada, rastu troškova kamata u svrhu financiranja dugova te proračunskim problemima $\mathrm{u}$ različitim državama.

Ray Dalio, milijarder i menadžer hedge fondova, upozorio je da bi američka ekonomija mogla $u$ roku od dvije godine krenuti prema recesiji, kada će izblijediti efekti smanjenja poreza koje je proveo američki predsjednik Donald Trump. Nakon toga je i investicijska banka JP Morgan izišla s analizom prema kojoj se 2020. može očekivati nova financijska kriza, i to zbog dugog trajanja trenutačne ekonomske ekspanzije, vrijednosti imovine, regulatorne klime i stupnja ukupne zaduženosti tvrtki i država.

Nouriel Roubini, profesor na NYU's Stern School of Business, ustrajno tvrdi "da će do 2020. sazrijeti uvjeti za financijsku krizu, koju će slijediti globalna recesija".

Neki analitičari, poput Kristine Hooper, strateške analitičarke u investicijskoj kompaniji Invesco, ne boji se toliko snage predstojeće krize, koliko činjenice da najveće centralne banke neće imati dovoljno manevarskog prostora da na nju odgovore, jer su već previše "napuhale" svoje bilance.

Bill Emmons, pomoćnik zamjenika predsjednika i ekonomist Federal Reserve banke u St. Louisu, mišljenja je, pak, da i ako dođe do sljedeće globalne financijske krize i recesije, ona ipak neće biti tako jako devastirajuća kao prethodna. S njim se slaže i Aaron Klein, direktor Centra za regulaciju tržišta pri Brookings Institution i bivši glavni ekonomist Bankarskog odbora u Senatu SAD-a, s tim da obojica smatraju da se nije dovoljno napravilo na regulativnoj zaštiti potrošača $i$ uspostavljanju još jačih regulatornih mehanizama za preveniranje i ublažavanje cikličnih kretanja ekonomije.

Diego Zuluaga, analitičar centra Cato Institute's for Monetary and Financial Alternatives, mišljenja je da bi do nove krize moglo dovesti to što država i dalje - kao i prije deset godina - ohrabruje neracionalno ponašanje potrošača, pogotovo jamčeći za bankarske depozite, hipotekarne kredite i studentske zajmove.

Ovaj kratki pregled mišljenja istaknutih nobelovaca i ekonomista završit ćemo $\mathrm{s}$ Markom Zandijem, glavnim ekonomistom tvrtke Moody's Analytics, koji je ustvrdio da u 2020. možemo očekivati "realnu točku preokreta" (engl. "real inflection point"), da bi se u nekim novijim nastupima korigirao i kazao da je teško predvidjeti kad će doći sljedeća kriza, ali da je američka i svjetska ekonomija još uvijek jako ranjiva.

\section{Financijski centri moći u strahu su od novog potopa}

Crno upozorenje odaslao je William White, predsjednik promatračkog odbora Organizacije za ekonomsku suradnju i razvoj (OECD).

„Situacija je puno gora nego što je bila 2007. godine. Nemamo više makroekonomske municije za novu borbu s krizom. Dugovi su se nastavili gomilati posljednjih godina te su dosegnuli toliko visoku razinu u cijelom svijetu da predstavljaju ekonomski odron koji samo što se nije dogodio $i$ koji prijeti uništavanjem svega ispred sebe. Nemamo ih čime servisirati!... „U idućoj recesiji - kako tvrdi bivši ekonomist Banke za međunarodna poravnanja - postat će očito kako se većina enormnih dugova neće moći tako lako otplatiti niti reprogramirati, a gomila ljudi naći će se u nebranom grožđu kada njihova imovina doslovno preko noći izgubi na vrijednosti" /15/. Upozorenje je stiglo u okviru Svjetskog ekonomskog foruma u Davosu. Jedino pravo pitanje bit će jesmo li sposobni suočiti se sa stvarnošću ili ćemo držati glavu u pijesku koliko god možemo. Da se nešto ovakvo 
sprema i logično je budući da je cikličnost dugova poznata unazad pet tisuća godina, još od doba Sumerana... "Ono što sada čeka svjetske vlade jest hvatanje u koštac s mnogobrojnim otpisima dugova koji nas očekuju. Samim time, tvrdi White, dogodit će se velika "pretumbacija" na svjetskom tržištu iz koje će niknuti novi gubitnici, ali $i$ novi pobjednici. Među ovim prvima, White vidi europske kreditore. Upravo će se na Starom kontinentu dogoditi najveći rezovi, a europske banke već su priznale kako je u optjecaju više od bilijun dolara nenaplativih i loših zajmova koje de facto već sada mogu otpisati. Najviše ih je uzeto od zemalja u razvoju, a sve kako bi se prekrili ili sanirali dosadašnji dugovi. Preciznije, novim zaduženjima (koja postaju teško naplativa ili uopće nenaplativa) saniraju se stari krediti. Zvuči li vam ovo poznato? „Nova pravila „bail outa" ili financijskog spašavanja, upozorava White, mogla bi opaliti po svima čija je štednja veća od 100 tisuća eura, ili otprilike nešto ispod jednog milijuna kuna". "Otpis dugova velikim državama će oni na kraju platiti - kazao je White na čije bi se riječi svatko trebao zabrinuti, ne samo oni s milijunskim štednjama.

Upravo je White još tamo 2005. godine vrlo jasno izjavio da financijski svijet Zapada ide prema krizi, te da se globalna ekonomija odjednom našla na samom rubu. Preko tog ruba je, kao što svi dobro znamo, i pala početkom 2008. godine krahom tržišta nekretnina u SAD$\mathrm{u}$ i teškom zloupotrebom tzv. financijske poluge. Tada je gorko potvrđena ona izreka (čiji korijeni sežu još u vrijeme prve svjetske ekonomske krize 1929. godine) da "kada SAD kihne, cijeli svijet dobije upalu pluća“.

\section{Novi kreditni mjehur}

Ovoga puta bi netko drugi mogao biti kliconoša... Netko tko je u međuvremenu postao toliko moćan da svijet zarazi upalom pluća

Kina. Naime, kako tvrdi White, nakon propasti globalnog financijskog giganta Lehman Brothersa, centralne su banke povećavajući ponudu novca odnosno kvantitativnog, te stimulirajući niske gotovo nulte kamatne stope kao i posuđivanje dolara zemljama u razvoju i državama istočne Azije, otvorile put stvaranju novog kreditnog mjehura koji bi mogao puknuti bilo kada. "Rezultat - poentira White - jest taj što su sada $i$ te zemlje upale $u$ spiralu duga". Kombinirano dug javne države i privatnog sektora kod zemalja u razvoju (u svijetu) u prosjeku sada iznosi 185 posto BDP-a. Kod OECD zemalja taj je postotak još veći i iznosi 265 posto BDP-a. U oba slučaja dogodio se rast od zabrinjavajućih 35 posto u odnosu na 2007. godinu. „Tržišta zemalja u razvoju su 2008. 2009. bila dio rješenja, a danas predstavljaju dio problema" - tvrdi White.

Budući da se radi o čovjeku koji je javno upozoravao na posljednju krizu mnogo prije njenog početka, te o jednom od glavnih autora nedavne studije G30 zemalja o budućnosti centralnih banaka, na njegove bi riječi trebalo obratiti pažnju. Bio u pravu ili ne. To je i razlog zbog kojega u "Telegraphu" za koji je White dao intervju napominju kako riječi kanadskog ekonomista "imaju posebnu težinu". Sam White se ograđuje od predviđanja preciznog uzroka sljedeće krize, ali napominje kako se svijet opet opasno šeta po ekonomskom rubu. "Globalni financijski sustav izgubio je svoje sidro i kao takav sve će više biti sklon kvaru "- kazao je bivši glavni ekonomist Banke za međunarodne pogodbe. Dakle, ne zna se što će točno pokrenuti škarice koje će opet početi "šišati" građane i vlade te pokrenuti nove lavine stečaja, ali jedan od vrlo izglednih kandidata, kao što je spomenuto, mogla bi biti - Kina.

Nižu se imena ekonomista koji najavljuju novu, veliku financijsku krizu što bi mogla zahvatiti svijet i zatresti ga dublje i gore od posljednje krize. Kažu da će opet krenuti iz Amerike, vjerojatno 2020. godine, pa objašnjavaju da tamošnji fiskalni i monetarni poticaji previše podižu stopu rasta američkoga gospodarstva i "pregrijavaju" ga, nakon čega mu slijedi "hlađenje". Dodaju tome previsoke cijene dionica, visoke cijene nekretnina u SAD-u i svijetu, spominju preveliki javni dug SAD-a i trgovinske ratove...Uklapaju $u$ tu sliku još tamnih tonova iz Europe pa vele da je velika likvidnost rezultat monetarne politike niskih kamata, čemu će doći kraj i pogoditi prezadužene europske države i građane, jačanje populističkih pokreta $u$ nekim državama usporava provedbu reformi... 


\section{Alarmi za krizu na tržištu duga}

Analitičari posebno upozoravaju na pregrijavanje ekonomije. McKinsey, vodeća svjetska konzultantska kuća, ističe obnovljenu zabrinutost zbog mogućnosti novog ciklusa recesije pa podsjeća na rad svojeg analitičara Tima Kollera koji tvrdi da se najava krize puno bolje iščitava na tržištu duga nego iz kretanja cijena dionica i roba. Upozorava da je kriza blizu u onom trenutku kada popuste kriteriji za zaduživanje građana, odnosno kada sve širi krug ljudi može podići kredit bez jasnih kolaterala, ali i onda kada padne likvidnost na tržištu duga, odnosno kada se dugom teško trguje. Unatoč dizanju kriterija i većoj zaštiti financijske industrije dug $\mathrm{u}$ bilancama raste /16/.

Od krize do danas stvorene su 72 tisuće milijardi novog duga, a samo su države povećale javni dug za dodatnih 60 tisuća milijardi dolara. S obzirom na niske kamatne stope na tržištu obveznica i visok interes ulagača, do problema s likvidnošću još nije došlo, ali činjenica da Italija tone $u$ recesiju, a "bilda" svoj javni dug koji je premašio 130 posto BDP-a upozorenje je koje se ne može ignorirati i koje bi se moglo pokazati kao mnogo veći problem od Grčke. Naime, Grčka je u najvećoj dužničkoj krizi imala javni dug od oko 400 milijardi eura, dok je dug Italije u ovom trenutku premašio 2000 milijardi eura.

\section{Zašto nobelovci najavljuju novu financijsku krizu}

Na godišnjicu smrti velikog ekonomiste Petera Druckera ugledni poslovni časopis Harvard Business Review objavio je na naslovnici zanimljivo pitanje: "Kuda ovo ide?" Nema sumnje da je pitanje usmjereno ekonomistima koji su pokazivali zbunjenost u pokušaju da daju odgovor na ključne dileme kriznog perioda koji je poharao svjetsku ekonomiju /17/. Iako je prošlo nekoliko godina od kako je Svjetski ekonomski forum debatom na temu "Je li kapitalizam 20. stoljeća iznevjerio društvo 21. stoljeća" identificirao rastuću ekonomsku nejednakost kao glavnu prijetnju socijalnoj stabilnosti, svjetski moćnici nisu uspjeli zaustaviti rastući trend nejednakosti.
Unatoč njihovim pokušajima, jaz između bogatih i ostatka svijeta $u$ petogodišnjem razdoblju se proširio, tako da prihodi i bogatstvo manjine rastu alarmantnom stopom. Primjera radi, Wall Street je krajem 2007. godine za bonuse top-menadžerima isplatio 39 milijarda dolara, samo godinu kasnije poreskim obveznicima položio računa na nekoliko tisuća milijarda dolara, a potom ponovo isplatio 117 milijarda dolara bonusa.

Na primjer, 1960. godine omjer plaće prosječnog direktora i predsjednika SAD-a bio je 2:1, a 2010. godine porastao je na 20:1. Isto tako, 1980. godine godišnja zarada top menadžera $u$ odnosu na prosječnu plaću radnika bila je u omjeru 40:1, a 2010. godine porastao je na 360:1. Da bismo bolje razumjeli ove brojke, osvrnimo se samo na podatak da je sedamdesetih godina jedan posto bruto društvenog proizvoda bio $u$ vlasništvu bogataša, dok je dvijetisućitih godina 33 posto bruto društvenog proizvoda $u$ njihovom vlasništvu.

Otac moderne ekonomske znanosti Adam Smith tvrdio je (još) prije 250 godina da je razina ostvarivanja nepravednog profita bila najveća $u$ slučaju ulaska država u ekonomsku krizu koja ih vodi u propast. To jednako vrijedi za pad starog Rima i raspad feudalnih država Europe i za trendove Amerike i Europske unije proteklih nekoliko godina. Kapital umjesto da služi realnoj ekonomiji postao je njezin vjerni sluga. Novčani tokovi zemalja postali su sofisticirane kockarnice koje slikovito možemo opisati spojem Wall Streeta i Las Vegasa.

Svake godine, tisuće najbogatijih i najmoćnijih vladinih dužnosnika, poduzeća i čelnika zajednice okupljaju se u Davosu u siječnju kako bi "definirali prioritete i oblike globalne, industrijske i regionalne planove", istaknuto je na ovogodišnjem sastanku Svjetskoga gospodarskog foruma. U izvješću se navodi kako se bogatstvo milijardera povećalo $\mathrm{u}$ prosjeku \$3.300,000.000 na dan, što predstavlja ukupan porast od 12 posto od 2017. U desetljeću od 2008. financijske krize, broj milijardera na svijetu skoro se udvostručio. Podaci se temelje na godišnjem popisu Forbesovih milijardera. Istodobno, bogatstvo koje drži najsiromašnija polovica svjetskog stanovništva smanjilo se za 11 posto između lipnja 2017. i lipnja 2018., 
navodi se u izvješću Credit Suisse i globalnoj bazi podataka o bogatstvu. /18/

"Shvatili smo da borba protiv siromaštva. postaje sve teža i teža zbog rastuće nejednakosti. To nas je dovelo do ideje da nekako 'zamijenimo zupčanike' $i$ fokusiramo se ne samo na pomoć u borbi protiv siromaštva, već i na ovaj ogroman jaz koji se stvara između super bogatih i ostatka čovječanstva, jer upravo to čini borbu protiv siromaštva težim. Svake godine vidimo kako je priča ista, ali (također se) pogoršava", kazala je Laureen Ravon, direktorica Oxfam International. /19/

„Umjesto da financijski sustav novcem i kreditima servisira proizvodnju, počeo se baviti izmišljanjem raznoraznih derivata koji donose kratkoročnu dobit, proglasio špekuliranje vrlinom, a pohlepu pretvorio u normu ponašanja". Zbog toga Nobelovci s pravom upozoravaju: nedovoljno pažnje se posvećuje nestabilnosti financijskih sistema i uzavrelim ekonomskim problemima. Ključni problem za ekonomiste nobelovce je taj što je većina zemalja izgubila suverenitet odlučivanja u ekonomskoj politici.

\section{Znakovi nove recesije}

Poslovna očekivanja $\mathrm{u}$ Europi $\mathrm{u}$ prvom tromjesečju su se smanjila, a izgledi $u$ Njemačkoj, koja je lokomotiva europskoga gospodarstva, naglo se pogoršavaju, upozorava njemački Institut za makroekonomiju i konjunkturna istraživanja - IMK iz Duesseldorfa. Glavni razlog za usporavanje ekonomije $\mathrm{u}$ svijetu jest promjena politike najvećih središnjih banaka, koje sada provode monetarno stezanje

Mediji u svijetu u posljednjih su mjesec dana zasuti proturječnim ekonomskim informacijama. Institucije poput Međunarodnog monetarnog fonda (MMF) $u$ najnovijim prognozama najavljuju nastavak procvata svjetskog gospodarstva. Istodobno, gospodarstvo se počelo blago usporavati. Neki promatrači vjeruju da to nije slučajnost, pa već od ožujka šalju alarmanta upozorenja. Tvrde da je globalno gospodarstvo prošlo vrhunac i da se već nekoliko mjeseci javljaju ozbiljni znakovi puzajuće recesije, koja će se u svijetu rasplamsati tijekom iduće godine. Nova kriza, koje nije bilo već jedno desetljeće, bit će po svojim razmjerima i posljedicama znatno šira i dublja od one iz 2008. godine, procjenjuju promatrači. Poslovna su se očekivanja u Europi $\mathrm{u}$ prvom tromjesečju smanjila, a izgledi $\mathrm{u}$ Njemačkoj, koja je lokomotiva europskoga gospodarstva, naglo se pogoršavaju. Čak i mala pogreška u politici može zemlju gurnuti u recesiju, alarmirao je sredinom travnja njemački Institut za makroekonomsku politiku i konjunkturna istraživanja.

\section{Pouzdani znakovi približavanja krize}

Opasnost od recesije značajno je povećana. Stanje je osjetno kritičnije nego prije mjesec dana - upozorio je IMK. Prema indikatoru tog instituta, izgledi za izbijanje recesije popeli su se na 32,4 posto, ponajprije zbog širenja trgovinskih napetosti i zbog naglog smanjenja likvidnosti u svjetskom financijskom sustavu. Taj IMK-ov indikator recesije sada je $u$ Njemačkoj znatno veći nego što je bio u ožujku 2008. godine, kada su Europa i svijet počeli kliziti u najveću krizu nakon Drugoga svjetskog rata.

\section{Sedam znakova približavanja krize}

- Rast gospodarstva u eurozoni u prvom tromjesečju prepolovio se $\mathrm{u}$ odnosu na prošli kvartal (izvor: JP Morgan)

- Pada potražnja za prijevozom brodskog tereta u svijetu, jer je indeks Baltic Dry ove godine pao više od 40 posto (izvor: Telegraph)

- Izgledi za recesiju u Njemačkoj danas su znatno veći nego u ožujku 2008. godine, kada se rađala tadašnja recesija (izvor: Institut IMK)

- Najveće središnje banke provode monetarno stezanje, pa u financijskom krvotoku ima sve manje raspoloživog novca (izvor: Saxo Bank)

- Libor je od počeka godine skočio na 0,6 posto, što znači da se banke boje međusobno posuđivati novac (izvor: Telegraph)

- Krediti poduzećima, u najvećim gospodarstvima u svijetu, gotovo su prestali rasti (izvor: Saxo Bank)

- Kamate na kratkoročni javni dug rastu i približavaju se kamatama na dugoročni dug, što je paradoks koji ukazuje na financijski stres (izvor: mediji)

Saxo Bank upozorava da se globalni indeks poslovne aktivnosti (PMI) od početka godine usporio na najnižu razinu u posljednjih 20 mjeseci. Stručnjaci te globalne investicijske 
banke iz Kopenhagena vjeruju da je riječ o pouzdanim znakovima približavanja recesije. Tako misli i Ambrose Evans-Pritchard iz britanskog Telegrapha, jedan od najpoznatijih, najcitiranijih i najbolje informiranih ekonomskih komentatora u svijetu.

\section{Povlačenje novca}

"Jasno je da se gospodarski bum eurozone iz 2017. ispuhao. Posljednjih tjedana došlo je do poplave razočaravajućih podataka o industrijskoj proizvodnji, maloprodaji i poslovnom povjerenju - kaže Evans-Pritchard. Prema njegovu mišljenju, koje dijeli i Saxo Bank, glavni razlog za posrtanje gospodarstva od početka godine u Euriopi i svijetu jesu politike najvećih središnjih banaka - američke, europske i kineske. One sinkronizirano provode monetarno stezanje. Umjesto bjesomučnog tiskanja novca - kojim su nakon krize iz 2008. nastojale stimulirati potražnju i gospodarski rast - one sada prestaju $\mathrm{s}$ upumpavanjem novca $\mathrm{u}$ financijski krvotok. Najdalje je otišla američka središnja banka (Fed), koja povlači novac s tržišta. Već šest puta je u tri godine podigla kamatnu stopu. Najavljuje da će do kraja godine monetarno stezanje ubrzati. To monetarno stezanje usporava rast monetarne mase $\mathrm{u}$ svijetu, pa se bankama i ostalim financijskim institucijama naglo smanjuje raspoloživi novac i kamate postupno rastu, prema riječima EvansPritcharda. Komentator Telegrapha procjenuje da će se smanjenje novčane mase negativno odraziti na gospodarstvo, i to s pomakom od šest mjeseci, u cijelome svijetu. I Europska središnja banka smanjila je nekadašnje financijske injekcije s 80 na 30 milijardi eura mjesečno, a do rujna planira potpuno prestati s monetarnim popuštanjem. Ako se to dogodi, Evans-Pritchard procjenjuje da će europsko gospodarstvo ući u recesiju za godinu dana, idućeg proljeća. Saxo Bank smatra vjerojatnim da će američko gospodarstvo pasti u recesiju »u sljedećih 12 do 18 mjeseci«.

\section{Skočio Libor}

To nisu jedini znakovi prijeteće recesije. Baltic Dry Index, koji pokazuje ponudu i potražnju u prijevozu pomorskog tereta $u$ svijetu, od početka godine pao je više od 40 posto - što također upućuje na posustajanje globalnoga gospodarstva, prema Telegraphu. Zabrinjava i rast Libora, referentne kamate stope po kojoj najveće banke u svijetu međusobno posuđuju novac. U normalnim vremenima Libor je manji od 0,1 posto, ali od početka godine skočio je na 0,6 posto, za pozajmice na rok od tri mjeseca, primjećuje Telegraph. Takav skok Libora u odnosu na službenu kamatnu stopu američkog Feda nije zabilježen još od početka financijske krize iz 2008., uočava Saxo Bank. Sve to potvrđuje da banke zbog smanjivanja raspoložive likvidnosti oklijevaju posuđivati novac. Radije ga drže kod sebe. Na to upućuje i zloguki rast kamata na kratkoročne dugove što je paradoks. Pravilo je da su kamate na dugoročni javni dug veće od onih na kratkoročni, jer su i dugoročni rizici za zajmodavce veći. Međutim, razlika između kamata na kratkoročne (dvogodišnje) američke državne obveznice i kamata na dugoročne (s dospijećem za 10 godina) trenutačno se smanuje. To je tipični simptom stresne situacije $\mathrm{u}$ financijskom sustavu, koja se ponavlja uoči izbijanja recesije, podsjećaju financijski stručnjaci. Ako se raspoloživi novac $u$ financijskom sustavu nastavi smanjivati, to može u nepovoljnom razvoju događaja dovesti do kreditnog sloma, upozorava Telegraph. Ekonomija ne može funkcionirati bez kredita. Kada oni rastu, gospodarska aktivnost jača. Kada krediti stagniraju, ekonomija posrće. Saxo Bank dodaje da se dugogodišnji kreditni bum nakon 2009. ispuhao - u Americi, Europi i Kini. Kreditni uvjeti se pogoršavaju. Rast kredita poduzećima u 18 zemalja, koje čine gotovo 70 posto svjetskoga gospodarstva, početkom godine spustio se se gotovo na nulu, dramatično upozorava Saxo. Dosad je prevladavalo mišljenje da šanse za izbijanje nove recesije nisu puno veće od 10 posto, ali optimizam naglo slabi.

"Nade u sinkronizirani rast brzo nestaju, jer globalno gospodarstvo posustaje (globalni PMI se srozao na najnižu razinu), a u SAD-u se javljaju upozoravajući znakovi usporavanja" - kaže Saxo. "Već spomenuti "pokazatelji upućuju na to da se SAD nalazi na kraju pozitionog poslovnog ciklusašto nije veliko iznenađenje - da nas recesija čeka iza ugla $i$ da je Trumpova ekonomska politika ne može spriječiti«, predviđa Saxo. 
Valja imati na umu da Telegraph i Saxo Bank nisu jedini vjesnici nove ekonomske krize $u$ svijetu. $\mathrm{Na}$ znakove recesije počeli su upozoravati mnogi američki ekonomisti, a nedavno im se pridružio ugledni Financial Times. Londonski list poručuje da središnje banke u ovoj osjetljivoj situaciji »ne bi smjele prestati s financijskim popuštanjem«.

\section{Obuzdavanje potrošnje}

Čini se da ni MMF više nema tako optimistično lice, kakvo je donedavno pokazivao. U travanjskom izvješću rekao je da se nad svijetom, usporedo s gospodarskim rastom, skupljaju i tamni oblaci. Iako je dvije godine tražio od država da povećavaju javne investicije $\mathrm{u}$ infrastrukturu, kako bi potaknule mlitavi gospodarski rast, MMF je u travnju naglo okrenuo ploču. Zatražio je obuzdavanje potrošnje i zaduživanja, zbog rekordnog porasta dugova u svijetu. MMF od država ponovno traži politiku proračunske štednje i smanjivanje proračunskih deficita, kako bi u crnim danima opet mogle povećati javnu potrošnju - čime bi amortizirale ekonomske nevolje.

"Ugradnjom takvih amortizera stvorit će se prostor za uvođenje proračunskih mjera koje bi podržale ekonomsku aktionost tijekom pada gospodarstva, kao i prostor za smanjivanje teškoća u financiranju, ako se globalni financijski uvjeti iznenada zaoštre, kaže MMF.

\section{Gdje je Hrvatska?}

Hrvatska se još nije ni osušila od kupanja u blatu prethodne krize. Tek ove godine Hrvatska će dostignuti realnu razinu BDP-a iz 2008. godine. Zatrese li svijet nova kriza Hrvatska neće proći bez ozljeda, a neki ekonomisti prognoziraju da će one ovisiti o tome kako će proći naši vanjskotrgovinski partneri Njemačka, Austrija i Italija. Drugi vjeruju da će ta nova kriza uništiti dio one industrije koja je preživjela prethodnu pa ukazuju da je i u prošloj krizi najveći danak plaćen u privatnom sektoru koji je prošao restrukturiranje i mnoga su radna mjesta nestala...Bez obzira odakle krenula, zbog globalne povezanosti potencijalna kriza će se odraziti na sve zemlje, pa tako i na Hrvatsku. Imajući u vidu dugi proces oporavka od prethodne krize, realno bi bilo predstaviti da bi nova kriza nanijela još ozbiljnije štete za hrvatsko gospodarstvo.

Stoga nije čudno što ni deset godina poslije upozorenja takve vrste, koja svako malo stižu od pojedinih svjetskih ekonomista, i $u$ Hrvatskoj ih slušaju s oprezom i s pomalo strepnje. Naime, većina središnjih banaka, počevši od SAD-a i drugih utjecajnih zemalja svijeta, u svojim istraživanjima upozorava na činjenicu da se povećava broj indikatora koji nagoviještaju recesiju. Ti indikatori, istina, još uvijek nisu prevladavajući, ali se njihov broj kontinuirano povećava i svi pokušavaju projicirati kada bi se to moglo dogoditi. Suština je $\mathrm{u}$ tome da problem nije riješen, pa glavni uzroci velike financijske krize 2007./2008. i dalje postoje.

"Brojni su rizici u ovoj godini, koji ukazuju na potencijalnu mogućnost nove globalne financijske krize. Primjerice, Deutsche Bank je navela popis od 30-tak takvih rizika (geopolitičkih, političkih, makroekonomskih, itd.)... Poznati monetarni ekonomista dr. Steve Keen upozorio je na generatore nove krize (prevelika zaduženost, nedovoljna nova regulacija financijske industrije, etc.). Izgledi za novu globalnu financijsku krizu su realni, iako je teško predvidjeti trenutak izbijanja nove krize".

Najveće svjetske ekonomije nalaze se na tankom ledu, zbog čega nemaju mogućnost uvođenja fiskalnih, monetarnih i hitnih mjera za borbu protiv nove globalne krize. Ona će biti gora i trajat će duže od one koja je 2008. godine uzdrmala cijeli svijet /20/. Nova ekonomska kriza ovog će puta krenuti iz SAD-a uzdrmat će i liberalnu demokraciju, što bi moglo dovesti do sloma svjetskog poretka kakvog poznajemo. Američki ekonomist Martin Feldstein upozorava da Amerika kao vodeća ekonomska sila više nema mogućnost preokrenuti neželjene ekonomske tokove.

"Na pragu smo nove recesije i kad ona dođe, bit će dublja i trajat će mnogo duže nego one iz prošlosti. Nažalost, nemao strategiju da to spriječimo. Nova kriza bit će gora od velike depresije iz 19. stoljeća $i$ one iz tridesetih godina 20. stoljeća", upozorava ekonomist /21/. Cijene nekretnina rastu, rastu i plaće, poslodavci radnike traže svijećom, investicije rastu, a svjetski ekonomisti najavljuju novi ciklus krize! Zvuči kao 
paradoks, ali rani znakovi s tržišta pokazuju da je vrijeme brzog rasta iza nas, a onima koji i dalje vjeruju u ekspanziju gospodarstva dovoljno je reći da je ekonomija bila najbrža netom prije sloma u 2008. godini. Kriza pred nama ne bi trebala biti ni približno intenzivna kao netom spomenuta svjetska financijska kriza, ali dovoljno će usporiti razvoj da bi je države poput Hrvatske itekako osjetile.

Da se iza brda valja nevolja za Hrvatsku, pokazuju i nedavne korekcije rasta Međunarodnog monetarnog fonda, ali i Europske komisije. Nijedna od te dvije institucije ne očekuje mnogo od njemačkog i talijanskog gospodarstva, naših najvećih trgovinskih partnera. Usporavanje industrije $u$ Njemačkoj i recesija u Italiji mogli bi snažno pogoditi izvoznike u Hrvatskoj, ali poremećaj bi se mogao osjetiti i u turizmu. Ako Talijani i Nijemci primijete pad standarda, mogli bi izabrati jeftinije turističke destinacije poput Turske, što bi se moglo negativno odraziti na granu koja Hrvatskoj donosi više od 17 posto gospodarskih aktivnosti. Iako se Hrvatskoj i dalje prognozira rast od 2,7 posto u tekućoj godini, čak i Ekonomski institut Zagreb upozorava da se treba računati na kontrakciju. Uvjereni su da se ona dogodila već u prošloj godini pa su tako objavili da je u cijeloj 2018. BDP rastao samo 2,3 posto.

Ekonomski institut upozorava da je CEIZ indeks u prosincu 2018. pao na najnižu razinu od kolovoza 2014. godine, a riječ je o indeksu koji pokazuje poslovne prilike. Gospodarstvo vuku privatna potrošnja i već spomenuti turizam. Građani su se lani gotovinskim kreditima zadužili rekordnih 5,4 milijarde kuna. Turizam je pod velikim pritiskom konkurencije, ali i pada standarda na nekim od emitivnih tržišta. Hrvatska nije iskoristila dvije faze rasta da znatno poveća standard svojih građana ni da promijeni strukturu svojeg gospodarstva, a jedva se oporavila od udara krize. Sada ponovno krizu dočekujemo nespremni uz činjenicu da su porezi već podignuti, a javni dug na znatno višoj razini nego 2008. godine kada je zauzimao tek 40 posto BDP-a.
Promjene u ponašanju poslovnog novinarstva Posljednje tri-četiri dekade nastupile su $u$ svjetskom gospodarstvu velike promjene, koje imaju ozbiljan odraz na mnoge dimenzije življenja. Potreba za vijestima o gospodarstvu raste gotovo geometrijskom progresijom, bilo da je riječ o financijama, poslovanju ili ekonomskim pitanjima. Financijsko i ukupno poslovno novinarstvo slijedi te promjene. $\mathrm{U}$ tim promjenama, međutim, novinarstvo gubi ili napušta svoju središnju ulogu - zaštitu javnog interesa. Teško je, naime, ustvrditi da su novinari koji pokrivaju područja ekonomije postali objektivniji ili odvažniji u zauzimanju nepopularnih stajališta. Mnogi medijski analitičari čak tvrde, vjerojatno s razlogom, da su postali lakovjerniji i manje revni u svojim izvješćima i analizama.

Izvješćivanje o poslovnim rezultatima prerasta u svojevrsnu tehniku. Urednici i novinari pokušavaju steći određene prednosti dajući svojim napisima privid veće autentičnosti, potpomognute izjavama i mišljenjima istaknutih poslovnih ljudi i akademskih stručnjaka, što se u dosta slučajeva pokazalo štetnim upravo sa stajališta zaštite javnog interesa. Novinarstvo općenito postaje samouvjerenije, novinari i poslovni komentatori preuzimaju ulogu stručnjaka, gdje se gubi razlika između mišljenja i činjenica, Raste pritisak na novinare da imaju izgrađene poglede i stavove na čisto tehnička pitanja.

Nedostatak tradicionalnog novinarskog skepticizma prerasta u ozbiljan gubitak, U SAD-u je ključna funkcija medija u izazivanju establišmenta, predstavljajući interese čitatelja i gledatelja, i promicanju, praćenju i nastojanju da se održi ravnoteža među prirodnim tendencijama u uspostavljanju moći u kontroli protoka informacija između ekonomije, vlade i stanovništva. Pomicanjem interesa i stupnja obrazovanosti novinara na područjima koja pokrivaju javlja se težnja potpunijeg razumijevanja kompleksnih procesa što dovodi i do razvoja reporterskih ekspertiza. Ipak, u tom nastojanju gubilo se najsnažnije novinarsko oruđe - izvještavanje. Akademici, politekonomisti i poslovni analitičari, osobito iz financijskih krugova, prečesto su postali glavni akteri vijesti i analiza, koje su mediji interpretirali javnosti. Rastom poslovnog 
novinarstva ono postaje dragocjen profitni centar, ali sve više osjetljiv na kretanje trendova. „Novo novinarstvo" traži sve više ono što nazivamo 'reporter opinion', dakle vlastiti stav prema nekom određenom pitanju. Pokazalo se da je u najvećem broju slučajeva taj stav izgrađen na stavovima njihovih izvora informacija. U isto vrijeme, novinarstvo u SAD$\mathrm{u}$ općenito prerasta $\mathrm{u}$ glamuroznost, $\mathrm{s}$ naglašenim osobama i celebrity pojavama. Poslovne vijesti podliježu sve učestalije takvom trendu. /22/

\section{Rast poslovnog izvješćivanja}

Rast poslovnog izvješćivanja na televiziji, posebno na kablovskim postajama, također utječe na promjene $\mathrm{u}$ prirodi kako se plasiraju vijesti iz gospodarskog i financijskog područja. Općenito, novosti na televizijskim ekranima mijenjaju se od neprofitnog javnog servisa prema zabavnom servisu koji omogućuje stvaranje profita. Tiskani i elektronički mediji postaju osjetljiviji na potrebe održavanja što većih naklada ili kvota gledanosti, javljaju se kraće vijesti i emisije kako bi privlačile što veći broj publike, a poticale su nepotpune debate i izazivale kontroverze, i pravo s namjerom da povećavaju čitanost ili gledanost, pri čemu se naglasak stavlja na osobnost voditelja, a manje na sam sadržaj emisije.

U tom procesu promjena u načinu izvještavanja i prezentiranja vijesti iz poslovnog svijeta poslovni su mediji prečesto zauzimali stranu agresivne promocije konsenzualnih stavova koje su servirali poslovni krugovi u svom interesu. Nije se vodilo računa koliko zainteresirana publika zaista vjeruje $u$ napuhana hosistička burzovna izvješća, koja su najčešće primali, a bila su potkrijepljena 'sigurnim' izvorima iz Wall Streeta. Separatni interesi su u najčešćem broju slučajeva dobivali. Tek nakon što je publika postala pesimistična $u$ pogledu stvarnog stanja američke i svjetske ekonomije poslovni mediji postaju kritičniji na gospodarsku politiku Vlade SAD-a i ukupnu poslovnu praksu, a tek nakon kreditne krize i velikih financijskih skandala postali su agresivniji prema načinu djelovanja najveće svjetske burze, koja bitno utječe na kretanja na svim ostalim velikim svjetskim tržištima novca. /23/
Sumirano, najveći broj medija koristi situaciju za bolje pozicioniranje na tržištu, $u$ nastojanjima da auditoriju pruža željeno štivo i zadrži njihovu pozornost. Istodobno, rast oglašivača je novi pritisak na medije, koji sili izdavače da osiguraju potreban prostor i atraktivnim sadržajem zaokupe zanimanje čitatelja i gledatelja, a ujedno zadrže odgovarajuće profesionalne standarde.

Otvoreno je pitanje je li ekspanzija poslovnih vijesti pridonijela boljem informiranju javnosti. Medijski analitičari tvrde da $\mathrm{u}$ mnogim područjima - nije. Zašto? U 60-im godinama ekonomija je cvala. Usprkos tome, business kao karijera nije bila odrednica mladih. Velika depresija, uvijek na pameti kao rezultat pogrešne gospodarske politike i financijske pohlepe, nije izbrisana iz nacionalne memorije. $\mathrm{Na}$ poslovanje se još uvijek gledalo $\mathrm{s}$ određenom dozom prezira, a na profit s velikim nepovjerenjem. $S$ rastom gospodarstva raslo je i zanimanje javnosti, što su poslovni mediji iskoristili za svoju ekspanziju. Poslovni lideri poput Lee Iacocca-e postaju zvijezde društvenog života. Forbes svojom objavom 400 najbogatijih (1982.) uspostavlja novu ljestvicu vrijednosti u suvremenom svijetu. Tvrtke na Wall Streetu dramatično povećavaju svoje službe za odnose $\mathrm{s}$ javnošću. Poslovno novinarstvo prečesto 'gazi' u vode pomodnih kretanja, ostavljajući po strani mnoge neiskorištene teme i neiskorištene gospodarske mogućnosti. Ujedinjeni bankari i brokeri ubrzo su pronašli metode kako stvarati nove poslovne subjekte i osigurati kretanje kapitala. Jamstva za založenu imovinu bila su uglavnom nedovoljno kontrolirana. Derivirana tržišta bila su nadgledavana manje strogo od prodaje vrijednosnih papira. To je u glavnim poslovnim listovima prolazilo sa zatvorenim očima. Tek se pojavom azijske financijske krize javljalo nešto kritičnih tonova, koji su ukazivali kako liberalizacija tokova kapitala, dakle potpuno slobodno tržište međunarodnog kapitala, svakako nije idealno stanje i može ozbiljno ugroziti međunarodni financijski poredak. Zašto? Premalen je broj najvažnijih ekonomista iz akademskih krugova i, jasno, s Wall Streeta ukazivalo na alarmantno stanje. Ekonomisti su općenito podržavali liberalizaciju tržišta, preuzimanje i stvaranje velikih financijskih 
entiteta i vjerovali da konkurencija na slobodnom tržištu može osigurati potrebnu ravnotežu. Najveći broj poslovnih novinara, posebno onih kojima je specijalnost financijsko tržište, vjerovali su stručnjacima i njihove stavove 'pretakali' u svoje vlastite. Tako su izvještavali javnost i komentirali aktualno stanje. Poznati kolumnist The Washington Posta Robert Samuelson, kojeg mnogi s pravom označavaju kao konzervativnog novinara, opisuje to stanje ovim riječima: „Imali smo blage primjedbe na ATM stope, ali ne i ozbiljan prosvjed na uspostavljanje opasne financijske snage $i$ sprege kapitala i partikularnih interesa"./24/

\section{Je li riječ o stvarno 'novoj ekonomiji'?}

Medijski entuzijazam prema novoj ekonomiji bio je, to je utvrđeno, na besprimjeran način prihvatljiv za čitatelje, oglašivače i Wall Street, koji je taj entuzijazam usmjeravao za podršku 'jedrenju' cijena dionica. Sofisticiraniji novinari grčevito su razvijali posebne teorije $u$ znak podrške tim stavovima i gledištima, smatrajući da su na pravoj strani, na strani eksperata. Nekoliko akademskih stručnjaka razvilo je nove teorije kako bi velikim idejama dali i potreban akademski kredibilitet. Upravo to je bilo ono što je bilo potrebno financijskim izvjestiteljima.

Izvještavanje o novoj ekonomiji bilo je zapaženo površno. Definicije o novoj ekonomiji mijenjale su se unutar 1970. do početka 21. stoljeća unutar istih medija. Prve definicije govorile su o ekonomiji usluga, zatim globalizaciji, kasnije o kombinaciji usluga, globalizacije i informatičke tehnologije. Konačno, Internet je unio dodatne promjene, nova ekonomija je postala - web. Nova ekonomija iz 90 -ih godina bila je bez presedana $u$ povijesti gospodarstva, predstavljala je novu industrijsku revoluciju.

„Tržište dionica poraslo je u skladu s poraslom snagom nove ekonomije“ - pisao je Business Week 1996. Blještavim izvještavanjem o uspjesima nove ekonomije mediji su pomagali neodrživoj i nerazumnoj razini cijena dionica, usmjeravajući sofisticirane i nesofisticirane ulagače na neprimjereno kupovanje, nalik na kupnju mjehurića od sapunice. Mediji posebno televizija, pomogli su $\mathrm{u}$ ohrabrivanju tzv. „dnevnog trgovanja“. Najbolji primjer tako neodgovornog ponašanja medija može se sagledati na slučaju propasti ENRON-a, relativno mlade energetske kompanije, koju je Fortune proglasio najinovativnijom kompanijom u SAD. Mnogi drugi istaknuti poslovni mediji nasjeli su na tu ocjenu. Veoma je mali broj analitičara kritički sagledavao pravo stanje kompanije i njenu stvarnu financijsku vrijednost, ali su te kritike ignorirane. Sudbinu ENRON-a znamo: mirovinski fondovi izgubili su stotine milijardi dolara, a tisuće i tisuće ljudi je izgubilo posao. Jesu li mediji i neodgovorni novinari izazvali ovu financijsku katastrofu? Oni su sudjelovali u podgrijavanju atmosfere $u$ kojoj je nova ekonomija bujala. No, pravi uzroci krize leže u prenapregnutom financijskom tržištu, na kojem su se izgubili stvarni regulatori i gdje su pomiješane kruške i jabuke. Velika pohlepa i vizija bez stvarnog pokrića platili su danak, a najvećim su dijelom stradali obični ljudi, koji su primamljeni blještavim rezultatima nerealnog rasta vrijednosti dionica i nametnutim sjajem nove ekonomije izgubili svoje ušteđevinu za stare dane $/ \mathbf{2 5} /$.

Ono što se mora zamjeriti poslovnom novinarstvu u cijeloj toj (i svim drugim) priči jest da je izgubilo osjećaj skepticizma i odgovornosti kao pas-čuvar javnog interesa. Postalo je previše ovisno o izvorima čije prikrivene interese jednostavno nije razumjelo ili ih je ignoriralo. Ponovno se u praksi pokazalo koliko mediji mogu nanijeti štete, kao i koliko dobra mogu učiniti kad se drže svojih profesionalnih standarda i normi ponašanja. Slučaj nove ekonomije pokazuje lakovjernost poslovnog novinarstva, koja se više ne bi smjela dogoditi, jer sa sobom nosi ogromne nepovoljne posljedice za veliki broj sudionika.

\section{Gdje je poslovno novinarstvo zakazalo?}

Ekonomisti i medijski stručnjaci još će dugo analizirati ulogu medija $u$ financijskoj $i$ gospodarskoj krizi iz 2008. Jesu li mediji pojačali boom na burzama prije no što je spekulantski mjehur puknuo ili su pravovremeno, možda i prerano upozoravali na pretjeranu zagrijanost tržišta dionicama i na neozbiljne poslovne bilance velikih kompanija? Jesu li bili trendovski usmjereni ili su se ponašali kao brana katastrofi?

American Journalism Review (ožujak 2003.) istražila je ponašanje poslovnih medija u SAD- 
$\mathrm{u}$ u vremenu prije recesije i krize. Došlo se do zaključka da su mediji djelovali prociklički, a zapostavili su svoju ulogu 'psa-čuvara'. Istina, bilo je kritičkih tonova, ali su se oni (iz)gubili u kolektivnom zanosu i svojevrsnom bunilu. /26/ Ono što začuđuje $\mathrm{u}$ toj analizi je kako novinarstvo radi 'bez pamćenja' i kako malo, usprkos elektroničkim arhivama, najpoznatiji mediji koriste vlastita istraživanja. Na primjerima Wall Street Journala i Business Weeka, ali i Wahington Posta AJR pokazuje da je u godinama buma Nove ekonomije 1997. i 1998. uvijek iznova bilo upozorenja i signala na neprimjerenu praksu koja ima elemente prevare i nečistog vođenja poslovnih knjiga, puno prije skandala s ENRO-om i Tyco-om, ali se nitko nije 'budio' iz burzovnog transa.

„Onaj koji analizira napise u medijima posljednjih pola stoljeća bit će iznenađen što su sve novinari iščačkali. Međutim, u njihovim vlastitim redakcijama ta su upozorenja bagatelizirana, a prevladava stav da je 'sustav' zdrav, da se financijskim analitičarima $i$ gospodarskim revizorima u načelu može vjerovati $i$ da će gospodarski i financijski boom potrajati zauvijek". /27/

Fortune je u proljeće 2001 iznio jednu od skeptičnih priča o ENRON-u, da bi samo osam mjeseci kasnije šef ovog koncerna proglasio ,jednim od najpametnijih ljudi'. Najzapaženiji nepovoljni utjecaj poslovnih medija odražava se kroz snažno personaliziranje i olako rangiranje. Dok je Business Week 1981. prvi put na svojoj naslovnici donio portret jednog poslovnjaka, u 2000. bilo je čak 18 takvih 'cover stories? Među glorificiranim menadžerima godine (listu donosi Business Week), kao i na listi najcjenjenijih svjetskih komanija (Fortune) stalno su bila prisutna imena koja su kasnije optužena za loše vođenje kompanija (Cisco, Lucent) ili čak zbog kriminalnih radnji (Tyco, Enron, WorldCom). Istina je da su poslovni magazini pred vodećim menadžerima još neposredno prije bankrota 'očarani mahali repom'.

Slično ponašanju poslovnih medija ponašali su se i televizijske postaje. Oni su davali prostor i vrijeme u udarnim terminima vodećim financijskim analitičarima i bili prepoznati kao burzovni gurui, iako se znalo da su uključeni u insider-poslovanje i javno preporučivali kunju akcija koju su poznatima preko e-maila objavljivali kao 'šrot'. U 90-im godinama je prevladavala standardna praksa da se preporuke burzovnih analitičara dalje šire, bez transparentnog objašnjavanja u kojoj su mjeri u igri vlastiti interesi. Pokazalo se da su novinari jednostavno slijedili krdo i na taj način postali žrtvom 'kolektivne neobjektivnosti'.

Columbia Journalism Review nastavila je istraživanja u pravcu uloge poslovnog novinarstva u stvaranju gospodarske i financijske krize. Objavila je listu od 727 novinskih priča, objavljenih u poslovnim medijima, obuhvativši razdoblje od 2000. do kataklizme u 2007. Cilj analize bilo je pokazati $\mathrm{u}$ kojoj su mjeri mediji s jedne strane pridonijeli krizi, a s druge što su (u)činili da bi se izbjegla katastrofa. Konačni zaključak je nepovoljan: nisu učinili ništa! U tom smislu, bez obzira na sve druge okolnosti, snose veliku odgovornost za nastalu krizu i gubitak povjerenja $u$ financijske institucije. Stečajevi Enrona, World Coma i Adelphia-e u 2002. ukazivali su na nadolazeću katastrofu, jer su uzroci bankrota bili uglavnom identični: loše i neodgovorno poslovno ponašanje $u$ pregrijanoj burzovnoj konjunkturi. Kapitalistički sustav, kako ga poznajemo, došao je $u$ fazu ozbiljne ugroženosti. Mnogi su ljudi počeli gubiti povjerenje $\mathrm{u}$ poslovne krugove. Gallup je $\mathrm{u}$ srpnju 2002. obavio anketu o povjerenju ljudi u pojedina zanimanja. Na vrhu liste bili su učitelji, a slijedili su ih mali poduzetnici. Vrhunskim menadžerima velikih kompanija povjerenje je poklonilo samo 23 posto anketiranih, a prodavačima automobila samo 15 posto. Ukratko, menadžeri su na toj listi prošli lošije od odvjetnika i vladinih službenika. Je li to trebao biti jasan signal? Očito s današnjeg stajališta da, ali je ukupna euforija bila presnažna da bi se spriječilo nastavak neodgovornog ponašanja.

Opseg i raznolikost izvještavanja o financijskim i burzovnim događanjima ovisni su o konjunkturi. Ta činjenica bitno utječe i na ponašanje gospodarstva, koje je počesto izloženo trendovima koje napisi uzrokuju, pa se $\mathrm{u}$ skladu $\mathrm{s}$ tim rukovode $\mathrm{u}$ poslovnim odlukama. Nije to samo američki sindrom: tako su se ponašali mediji $i$ poslovni krugovi $u$ Velikoj Britaniji, Njemačkoj, Francuskoj, čak i 
Švicarskoj. Azijske burze su bile nešto suzdržanije, ali kriza je i njih zahvatila. Tako je dezinformacija zapravo postala vodeća snaga Nove ekonomije, koja je dovela do kolateralnih nepovoljnih učinaka.

U studiji koju je razradila zaklada Otto Brenner $\mathrm{u}$ Frankfurtu pod naslovom : Poslovno novinarstvo u krizi- masovno medijalno ponašanje na financijskim tržištima" John Talbott, nekadašnji bankar Goldman-Sachs, jasno piše: „Kad jedna skupina bankara kasira stotine milijardi USD kao bonus za zasluge što su širom svijeta uništili bilijarde dolara kroz imovinu $i$ stotine milijuna radnih mjesta, želimo znati koju ulogu je novinarstvo odigralo"./28/

Opetovano se pokazalo da je poslovno novinarstvo uvjereni sluga mainstreama, a ne kritički raspoloženi tragač za otkrivanjem prave istine. U području gospodarstva, koje ima veliku važnost u ukupnim društvenim kretanjima, prevladava duh 'dnevnog novinarstva' koje nudi malo informacija i uzrokuje mnogo dezorijentiranosti. Njemačko poslovno novinarstvo je kao promatrač, izvjestitelj ili komentator financijskih tržišta i financijske politike sve do izbijanja globalne financijske krize loše djelovalo. Najpoznatije dnevne novine u Njemačkoj tek su se kroz slom krize publicistički i novinarski 'razbudile'.

Malo je poznato da su američki intelektualci poput Noama Chomskog i Edwarda Hermana još prije nekoliko godina u svojoj knjizi Manufacturing Consent: The Political Economy of the Mass Media grubo razotkrili kako masovni mediji djeluju u sprezi s vladama, oglašivačima i gospodarskim poslovnim krugovima. Većina vijesti koja se plasira $u$ javnost najvećim je dijelom lažna ili nepotpuna, kako bi se izašlo ususret interesima velikih kompanija koji kontroliraju, pa čak i posjeduju glavne medije. Poopćavanje uvijek u sebi krije opasnost poistovjećivanja, ali u ovom slučaju je vrijedno šire pozornosti.

Dosje "Financijska kriza i mediji“ koji je predstavljen na 13. Medijskom disputu $u$ Mainzu (3. prosinca 2008.) ukazao je na brojne slabosti poslovnog novinarstva u Njemačkoj, polazeći od osnovne teze da financijska kriza stavlja na kušnju poslovno i financijsko novinarstvo. U vremenu kad se mijenja tempo događanja i kad su dosad uvriježena načela jednostavno odbačena, moraju se i kroničari ove branše prilagoditi tim promjenama. Siegfried Weischenberg, profesor novinarstva na Sveučilištu u Hamburgu, kaže: „Smatram da je struktura današnjeg poslovnog novinarstva, ali $i$ gospodarske znanosti u našem društvu pogrešno postavljena: potpuno su slijepi ma kritike kapitalizma $i$ tržišnog gospodarstva u kriznim vremenima“. /29/

\section{Mediji kao ubrzivač financijske krize i gospodarski pad?}

Jesu li mediji i neodgovorni novinari izazvali ovu financijsku katastrofu? Oni su sudjelovali u podgrijavanju atmosfere $\mathrm{u}$ kojoj je nova ekonomija bujala. No, pravi uzroci krize leže u prenapregnutom financijskom tržištu, na kojem su se izgubili stvarni regulatori i gdje su pomiješane kruške i jabuke. Velika pohlepa i vizija bez stvarnog pokrića platili su danak, a najvećim su dijelom stradali obični ljudi, koji su primamljeni blještavim rezultatima nerealnog rasta vrijednosti dionica i nametnutim sjajem nove ekonomije izgubili svoje ušteđevinu za stare dane. Gubici se penju na stotine milijardi dolara. Financijska kriza ima velik utjecaj na realno gospodarstvo, kao što sada vrlo dobro znamo. Jasno je također da mediji imaju značajan utjecaj na očekivanja pojedinačnih gospodarskih agregata. Sa svojim vijestima (posebno naslovima) mediji pružaju znatan dio unosa informacija koji se nalazi na početku procesa obrade informacija. Budući da ljudi ne mogu pronaći, odabrati i obraditi sve relevantne informacije zbog ograničenog vremena i kognitivne sposobnosti, oni su vođeni ovim odabranim porukama i često samo naslovi imaju višu vrijednost memorije od tekstualnog sadržaja. Loše vijesti su dobre vijesti za medije. Razlog je jasan: mediji slijede vlastitu logiku poslovanja, a to je da loše vijesti prodaju bolje od dobrih vijesti. Loše vijesti stvaraju strahove. Budući da strahovi često proizlaze iz neznanja o međuodnosima procesa i procesa, prijenos znanja i informacija može smanjiti ili potpuno ukloniti strah. Kroz taj mehanizam, strahovi stvaraju veću potrebu za informacijama, a time i veću prodaju među proizvođačima medija. Naravno, bilo bi naivno reći da mediji samo jednostrano izvješćuju kako bi povećali svoje prihode. Takav prikaz ne bi 
primjereno odražavao složene procese odlučivanja u uredničkim uredima. Ipak, ostaje činjenica da mediji doprinose povećanju nesigurnosti u stvaranju očekivanja. Ako se slažemo s tim, moramo se složiti i s tezom da mediji ubrzavaju financijsku krizu i gospodarski pad. To ne znači da se ponašaju neodgovorno $u$ odabiru i obradi informacija. Čak i više, ne bi bilo primjereno prikazati ih kao (ozbiljne) uzročnike krize i gospodarskog pada.

Međutim, trenutačno stanje u gospodarskim i financijskim krugovima očigledno ukazuje na krizu (međusobnog) povjerenja, što stvara znatnu nesigurnost $\mathrm{u}$ pogledu budućih očekivanja poduzeća i ljudi. Mediji mogu pridonijeti smanjenju i pojašnjavanju te nesigurnosti. Konačno, vrijedno je zapitati: Što se promijenilo $\mathrm{u}$ odnosu na razdoblje prije velike financijske i gospodarske krize iz 2008? Naveli smo brojna razmišljanja nobelovaca za ekonomiju (pretpostavljam da su to relevantni čimbenici) koji ukazuju na opasnost od nove velike krize. Jesu li novinari i ukupno poslovno novinarstvo naučili lekciju iz prethodne krize? Bojim se da nisu. U godinama koje su vodile do financijske krize koja je započela u 2007, financijski mediji objavili su i emitiraju brojna upozorenja o potencijalnim problemima, posebno onima koji uključuju pregrijanu stambeno tržište. Ipak, nije bilo usklađenih napora da se upozori da će se cijeli financijski sustav možda srušiti. Kako je moglo i biti, kada velika većina stručnjaka - u poslovnim školama, u federalnim pričuvama, na Wall Streetu - nije mislila da je sudar na putu? Pravo je pitanje očekuje li nas sličan scenarij i u sada pregrijanoj euforiji i uzletu gospodarstva.

Ključno je pitanje kako gledamo na novinarstvo, posebno ono koje se preteži bavi gospodarskim i financijskim pitanjima i što od njega očekujemo? U kojoj mjeri komercijalizacija svih medija utječe na vjerodostojnost i istinitost prikazivanja objektivne stvarnosti? Praksa pokazuje da ta komercijalizacija i globalizacija medijske pozornice dovodi do fenomena personalizacije, emocionalizacije, dramatizacije, polarizacije, bulevardizacije te logike komunikacije i prodaje koje vode u infotainment, a zapostavljaju kvalitetu, točnost i činjenice. Samo novinarstvo mora dati konkretne odgovore na ova pitanja: zadržava li svoju tradicionalnu ulogu društvenog psa- čuvara ili je gubi odnosno napušta? Ovo se pitanje postavlja u svoj svojoj ozbiljnosti, jer živimo u vremenu kad su pouzdani mediji sve važniji za funkcioniranje političke javnosti i demokracije upravo zbog dubokih društvenih i gospodarskih promjena, pa time i svake države ponaosob.

U međuvremenu se naziru znaci laganog oporavka svjetske konjunkture. Pojedini mediji već padaju u euforiju: kriza je iza nas, ponovno se uspjelo. Stvaraju se lažne nade, pri čemu se zaboravlja krhkost financijskih tržišta, bez obzira što se poduzimaju ozbiljne mjere za njihovu stabilizaciju. Praksa pokazuje da svjetsko gospodarstvo pada iz jedne $\mathrm{u}$ drugu krizu, i da je to gotovo nezaustavljiv proces. $U$ tom uloga poslovnog novinarstva raste: upravo ono treba označiti trendove, postavljati prava pitanja u pravo vrijeme i pravim osobama. To je formula budućnosti, jer time poslovno novinarstvo jasno pridonosi dodanoj vrijednosti informacije i bitno utječe na ukupna gospodarska i financijska kretanja.

\section{Notes}

/1/ Fruehauf M., Schaefers M., Mussler W. (2019). Neue Regulierung: Sind die Finanzmaerkte jetzt wirklich stabiler? FAZ, 14.03.2019

/2/ Bloomberg (2018) What role did the media have in the financial crises? The banking enquiery wants to find out. 13.09.2018

13/ Augusto Lopez-Claros je bivši direktor grupe globalnih pokazatelja u grupi Svjetske banke, odjela odgovornog za izvješće banke Doing business i drugih međunarodnih komparativnih studija. Ranije je bio glavni ekonomist i ravnatelj globalnog programa konkurentnosti na Svjetskom gospodarskom forumu u Ženevi, gdje je bio i urednik globalnog izvješća o konkurentnosti, vodeće publikacije foruma, kao i niza regionalnih gospodarskih izvješća.

/4/ U Sjedinjenim Američkim Državama, na primjer, 78,000.000 osoba rođeno je između 1946. i 1964. ("Baby Boomers"), a ova kohorta započela je mirovinu u 2011. A to nije problem samo $u$ bogatim industrijskim zemljama. Kina, Indija, Rusija, Poljska, Indonezija, Turska i Meksiko, dakle zemlje s velikim brojem stanovnika, imaju sve stariju populaciju. Dakle, u nadolazećim 
godinama i desetljećima bit će fiskalnih pritisaka koji nisu bili prisutni krajem 1940-ih i 1950-ih, a to će znatno povećati proračunski teret i smanjiti sposobnost vlada da jednostavno "rastu iz duga".

15/ Robert James Shiller je američki ekonomist (dobitnik Nobelove nagrade u 2013.). Od 2018. je profesor ekonomije na Sveučilištu Yale i čelni je čovjek na Yale školi menadžmenta

Međunarodnog centra za financije. Shiller je bio istraživački suradnik Nacionalnog zavoda za ekonomska istraživanja (NBER) od 1980, bio je potpredsjednik Američke gospodarske udruge u 2005, a predsjednik istočne gospodarske udruge za 2006 - 2007. Vidi Why the Stock Bubble Will Burst Quickly: Yale's Shiller, Investopedia, 26. lipnja 2019

/6/ Nesbith J., Aburdane P. (1982). Megatrends information Society

/7/ Kampel A. (2012), studija Informazionseffenziens auf Aktienmaerkten, Examinus Publishing

/8/ Worldpress.com: RISE OF INFORMATION ECONOMY

/9/ Nouriel Roubini, američki ekonomist, postao je općepoznato ime u svijetu financija i ekonomije prije nešto više od deset godina kada je upozoravao na nadolazeću financijsku krizu. Njegova upozorenja ticala su se prave poplave pretjeranog davanja zajmova te zelenaškog karaktera i unutrašnje uvezanosti financijskog sistema, koja je kulminirala povijesnom financijskom krizom i bolnom recesijom 2008. i 2009. godine.

/10/ Nouriel Roubini \& Brunello Rosa: Is the next financial crises already brewing?; Financial Times, september 11, 2018

/11/ Ibid.

/12/ Paul Krugman dobitnik je Nobelove nagrade za ekonomiju za 2008. godinu

/13/ Vidi kolumne Paula Krugmana: Trump will bring global recesion, Politico, 11. rujna 2018; Trump makes America irresponsible again, NYT, 3. lipnja 2019; Trump is losing his trade wars, NYT, 4. srpnja 2019.

/14/ Nobelpreisträger warnen vor nächster Finanzkrise; Die Welt, 21. kolovoza 2017.

/15/ The Telegraph: Former BIS Chief Economist Warns of Massive Debt Defaults, Need for Debt Jubilee; Fingers Europe as First in Line, Naked capitalism, 26.siječnja 2016.

/16/ You Tube: Tim Koller - Behind the number

/17/ Harvard Business Review: November/December 2017

/18/ Canad's National Observer, Obscene gap between rich and poor, 21. siječnja 2019 ..

/19/ Oxfam International je konfederacija neprofitnih organizacija, koja djeluje u više od 90 zemalja svijeta u borbi protiv siromaštva. Svake godine izdaje posebnu publikaciju, ali podnosi i WEF-u izvješće $u$ tom pogledu.

/20/ Nedavno je Školska knjiga objavila knjigu "Monetarna politika Europske središnje banke: ciljevi, institucije, strategije i instrumenti" izvanrednog sveučilišnog profesora ekonomije dr. Dubravka Radoševića. . U razgovoru za N1 govorio je, među ostalim, o mogućoj nadolazećoj globalnoj financijskoj krizi.

/21/ Wall Street Journal: Stock will face downward pressure from rasing interest rates, 17. siječnja 2018.

/22/ Televizija i tiskani mediji i dalje su primarni izvor informacija o ekonomskim pitanjima, rezultat je istraživanja koje je sproveo američki Pew Research Center I objavio 16. srpnja 2009. Kako prenosi European Journalism Centre, radio, televizija i tisak popularniji su izvor informacija o ekonomskim pitanjima nego internet. To je rezultat istraživanja američkog Pew Research Centra, prema kojem je preko 80 posto ispitanika izabralo TV i radio kao primarni izvor informacija o ekonomskim zbivanjima, 64 posto informacije traži u novinama i knjigama, a tek 48 posto na webu.

/23/ Činjenica je da gospodarstvo preuzima kormilo u svjetskim zbivanjima i svi procesi internacionalizacije, globalizacije i drugi aktualni procesi vezani su gotovo isključivo uz gospodarske tokove, odnosno uz politiku koja kroz gospodarsku (pa i medijsku ) supremaciju želi uspostaviti novi svjetski gospodarski poredak. Živimo, zapravo, u svijetu gdje jači i moćniji određuju pravila igre, kao i mjerila ponašanja i djelovanja. Svijet interesa i svijet nasilja ulaze u nasilnu preraspodjelu svih odnosa $\mathrm{u}$ društvu. Čini to, prije svega, kroz nove vlasničke odnose. Sigurno je da nam tek predstoji ozbiljna analiza ukupnoga stanja, uključujući i stvarne vlasničke odnose u svim medijima, a ne samo u tiskanim.

/24/ Trka za senzacijama, aferama, neozbiljno ili loše istraživanje, jednostrano izvješćivanje, rastuća tendencija $u$ pravcu zabave, nezamjeranje utjecajnim političarima i značajnim gospodarskim subjektima i tzv. 'puzajuća propaganda' - prije svega zbog spomenutih političkih i ekonomskih ograničenja novinara i nakladnika - loš su saveznik istinskog poimanja uloge medija i na neprimjeren način zamućuju ukupnu medijsku sliku, a posebno njen istinski tržišni karakter.

/25/ Nova ekonomija je pojam koji se koristi za tranziciju od industrijskog u društvo zasnovanog na znanju i tehnologiji. Znanje nije samo kritičan faktor sve bržih promjena, već je i činilac brzih transformacija starih ekonomskih paradigmi i 
starih koncepcija menadžmenta. Nova ekonomska paradigma zasniva se na intelektualnom kapitalu, informacijskim i telekomunikacijskim tehnologijama, ekonomskoj liberalizaciji i globalizaciji.

/26/ Analiza „Financial Crises and Media“ obuhvatila je 727 novinskih priča objavljenih u poslovnim medijima, obuhvativši razdoblje od 2000. do kataklizme u 2007. Cilj analize bio je pokazati u kojoj su mjeri mediji s jedne strane pridonijeli krizi, a s druge što su učinilii da bi se izbjegla katastrofa

/27/ Ibid

/28/ Autori studije su Hans-Juergen Arlt i Wolfgang Storz. Studija objavljena u Frankfurtu u veljači 2010.

/29/ Die Finanzkrise und die Medien: Nagelprobe fuer den Wirtschafts- und Finanzjournalismus, MainznerMedienDisput, prosinac 2008

\section{Literature}

1. Amcoff, E. (2010). The Role of Innovation Journalism in Business Journalism; The Wall Street Journal

2. Arlt, H.J.; Storz, W. (2010). Wirtschaftsjournalismus in der Krise - Zum massenmedialen Umgang mit Finanzmarktpolitik; Otto Brenner Stiftung, Frankfurt

3. Drašković, M. (2010). Uzroci globalne financijske krize, Ekonomija, Rifin, listopad 2010, strana 181198, Zagreb

4. European Journalism Observatory: Trendverstaerker oder Fruehwarnsystem? Die US-Wirtschaftspresse im New-Economy-Boom; www.ejo.ch/analysis/businessjournalism

5. Finanzkrise und die Medien: Kein Journalist kannte die Risiken. Razgovor s Thomasom Glocerom, voditeljem Službe za poslovne informacije u Thompson-Reutersu. Die Zeit, 08.09.2013.

6. Gavranović, A. (1999). Ugled novinara i vjerodostojnost medija; izlaganje na Međunarodnom simpoziju 'O imidžu i ulozi novinara u široj društvenoj percepciji', Dubrovnik
7. Hellwig, M. (2008). Risk in the Financial Sector An Analysis of the Subprime-Mortgage Financial Crisis; Max Planck Institute for Research on Collective Goods, Bonn

8. Markham, J. W. A financial history of modern U.S. corporate scandals: from ENRON to reform; http://books.google.com/book?id

9. Mast, C. (2006). studija „Vjerodostojnost - ključ komunikacije", Sveučilište Hohenheim u Stuttgartu, Njemačka

10. Medien Monitor; Die Finanzkrise in den Medien; www.medien-monitor.com, 17. Veljače 2010 Uebereuter 2001.

11. Schmitz, A. (2010). Fuenf Thesen zu Parallelen von Wirtschaftsjournalismus und Finanzbranche, Dinner Speech, Frankfurt, 4. svibnja 2010.

12. Stiglitz, J. (2002). Globalization and its Discontents; W.W. Norton Company, New York, 2002.

13. Studija o vjerodostojnosti blogova "Edelman Trust barometar"

14. Tambini; D., Polis (2008). What is Financial Journalism For? Ethics and Responsibility in a Time of Crises and Change; Univeristy of the Arts London College of Communication, Journalism and Society, November 2008.

15. Ulrich, K., Puschmann, D. (2007). Die neue Grammatik der Wirtschaftsmedien Ueberlegungen zur Zukunft des Wirtschaftsjournalismus, seiner Rezeption und seiner Geschaeftsmodelle, Koeln

16. Utjecaj globalizacije na novinarstvo, ICEJ, Zagreb 2006.

17. Watson, R. (2008). Future files: The 5 Trends That Will Shape the Next 50 Years, Nicholas Brealey Publishing, London-Boston

18. Wilby, P. (2008). When business journalism gets in bed with the financial institutions, Online Journalism News, 9. listopada 2008.

\title{
THE WORLD HAS (NOT) LEARNED A LESSON FROM THE FINANCIAL CRISIS
}

\author{
Ante Gavranović \\ Croatian Communication Association, Zagreb, Croatia
}

Abstract 
The great financial and economic crisis is a real school example of an economic disaster of incomprehensible proportions. Although (to this day) there is still not much consensus on the causes of this crisis, most experts recognize the culprits of the crisis, most notably in a financial system that has shied away from control and avoided regulation and supervision. More than ten years after the onset of the financial crisis, central bankers and politicians are patting their backs: the worst is behind us and the recovery is done. Error. It's only a matter of time before the crisis breaks out again. And with full force ... The Macroeconomic Resilience Index (jointly developed by the Swiss Institute of SRE - Swiss Re and the British University LSE - London School of Economics) shows that the global economy is less resilient to the global financial crisis today than it was in 2007. The analysis shows that 80 percent of countries (covering 31 countries with a $75 \%$ share of world GDP) is now more vulnerable in this respect, despite the fact that financial institutions are stronger and stronger than they were at the beginning of the crisis. The argument goes that the available shock absorbers for crisis management are weaker today than they were then. A World Bank blog recently published an article authored by Augusto Lopez-Claros, former Director of Global Indicators and Analysis at the World Bank. It is interesting for a number of reasons: especially since it is committed to fiscal stabilization in the coming years. He warned that in many countries public debt today is at levels last seen at the end of World War II. In his view, some form of fiscal consolidation, supported by other structural and institutional reforms, may be the only viable path in the coming years. He also makes three arguments in support of this claim. These are overall reduced fiscal space, then increased medium-term pressures and, finally, financial market volatility. How did journalists and general business journalism react to the onset of the financial crisis and what have we learned from it? Is the new financial crisis really on the wane?

\section{Keywords}

finance crises, financial systems, economic theory, understanding economic logic, solving problems 